Article

\title{
Corporate Social Responsibility: Motives and Financial Performance
}

\author{
Muhannad Atmeh, Mohammad Shaban and Malek Alsharairi * \\ School of Management and Logistic Sciences, German Jordanian University, Madaba 11180, Jordan; \\ muhannad.atmeh@gju.edu.jo (M.A.); moh_sh89@hotmail.com (M.S.) \\ * Correspondence: malek.alsharairi@gju.edu.jo
}

Received: 17 September 2020; Accepted: 25 November 2020; Published: 27 November 2020

\begin{abstract}
The relationship between companies and society has been questioned for a long time. However, the effect of the motives behind CSR regarding the companies' actual engagement with CSR has received little attention, especially in emerging markets. This paper tackles this issue for the first time using a sample of Jordanian companies. We explore the effect of two types of motives on the level of engagement in CSR: extrinsic motive (financial) and intrinsic motives (ethical and altruistic). The relationship between the company's actual financial performance and CSR is also investigated. Primary data were collected using a questionnaire, distributed to Jordanian company's managers in five sectors: pharmaceutical, technology and telecommunication, construction, farming, and financial services. Multiple regression analysis was conducted to depict the relationships. Results show that the intrinsic motives have a significant effect on CSR, while the extrinsic motive has none. When intrinsic motives were tested separately, results showed that the ethical motive had a significant effect, while the altruistic had no effect. In both cases, CSR was shown to be more significantly driven by the company's financial performance. Different stakeholders such as policymakers, entrepreneurs, researchers, and investors may use the results of this study to increase companies' involvement in CSR.
\end{abstract}

Keywords: corporate social responsibility (CSR); extrinsic motives; intrinsic motives; financial performance

JEL Classification: M14

\section{Introduction}

Corporate social responsibility (CSR) is a topic that has recently attracted attention. Researchers have been investigating the definition of CSR (Freeman and Hasnaoui 2010), the relationship between CSR and the financial performance of companies (Barnett and Salomon 2012), and how CSR is operationalized and measured (Graafland et al. 2004). CSR could be viewed by an individualistic society differently than a collectivist one (Hofstede Insights 2020), but the variation may be attributable to the different corporate motives underlying CSR engagement.

The relationship between companies and their societies has been questioned since the creation of the corporate form of business. Many scholars pointed to Howard Bowen as the first writer who theorized this relationship in a systematic way (Lee 2008). In order to determine whether businesses fulfill its social responsibilities or not, Bowen defined the social responsibilities of businessmen as "the obligations of businessmen to pursue those policies, to make those decisions, or to follow those lines of action which are desirable in terms of the objectives and values of our society" (Bowen 1953, p. 6).

In 1977, about half of the Fortune 500 firms mentioned CSR in their annual reports. By the end of the 1990s, approximately $90 \%$ of the Fortune 500 firms had adopted CSR as an important element in 
their objectives and actively promoted their CSR acts in their annual reports (Boli and Hartsuiker 2001). The concept of CSR has recently become more universally adopted and promoted by companies, governments, NGOs, and international organizations such as the United Nations and the World Bank (Lee 2008). Freeman and Hasnaoui (2010) argue that there is no single clear definition of CSR, not between nations or even within the same country. This supports the view of Matten and Moon (2008), who dictate that satisfactorily defining CSR is not a simple process because "CSR is an umbrella term overlapping with some, and being synonymous with other, conceptions of business-society relations." However, the common attribute among the different definitions of CSR is that companies are expected to act in a way that demonstrates a consideration towards society's needs (Graafland and Schouten 2012). For example, McWilliams and Siegel (2001) define CSR as the "actions that appear to further some social good, beyond the interests of the firm and that which is required by law." European Commission (2001), upholding the EU treaties and managing the day-to-day business of the EU, defines CSR - which is adopted in this study - as "a concept whereby companies integrate social and environmental concerns in their operations on a voluntary basis, beyond legal requirements."

The general objective of this paper is to investigate the role of motives in driving a firm's engagement in CSR activities. Specifically, we examine whether extrinsic or intrinsic motives lead to greater engagement in CSR. Further, we examine the effect of financial performance on CSR to explore the consistency of the evidence reported in the literature within the Jordanian context. Documenting evidence using a sample from Jordan enables us to know more about the collectivistic societies. Interestingly, Jordan's low score of individualism on Hofstede's model indicates that it is considered a collectivistic society (Hofstede Insights 2020).

Given the significance and role of CSR in societies, a better understanding of its underlying motives has implications for policymakers among other stakeholders. The literature reveals that motives could be extrinsic, i.e., economic, or intrinsic, i.e., ethical (Graafland and Ven 2006; Graafland et al. 2004). However, examining the effect of the motives behind CSR on the companies' actual engagement with CSR remains unanswered and has received little attention (Dare 2016).

This paper contributes to the existing literature by documenting evidence on the underlying motives that stimulate the companies in Jordan to engage in CSR and to examine whether a firm's financial performance has an impact on its engagement in CSR. In Section 2, literature regarding the evolution of CSR and its motives is presented. This includes the extrinsic motive, intrinsic motives, and actual financial performance. The measurement tools used in the literature for the different variables are illustrated, and the related studies conducted on the Jordanian companies are reviewed. The theoretical framework and the study hypotheses are developed in Section 3. Section 4 establishes the methodology of the study in terms of the variables metrics, the study population and sample, and the reliability and validity of the tools, followed by the empirical findings and conclusion.

\section{CSR: The Underlying Motives and the Actual Financial Performance}

Adam Smith claims that by pursuing only their self-interests with no regard to others' interests, market participants would unintentionally promote the optimal general benefit to society (Stovall et al. 2004). In view of that, CSR has no merits and demanding it is even not rightful. Milton Friedman, a Nobel Laureate of 1976, evidently opposed CSR directly by the firm and argued that it is an unfair additional cost on owners by stressing that the only social responsibility of businesses is to increase profits (Friedman 1970). A gradual and progressive shift in CSR acceptance was noted at the beginning of the 20th century. Bowen perceived CSR as a helpful tool that could help in solving problems associated with the free market (Bowen 1953, pp. 14-21). Further, Wallich and Mcgowan (1970) argue that the modern structure of corporations and the interest of shareholders had been modified in a way where the long-term interests of shareholders are in line with CSR. In the same context, Carroll suggested a framework of CSR that includes four groups of responsibilities: economic responsibility (the role of production in exchange for profits), legal responsibilities (to comply with the framework of the legal system), ethical responsibilities (activities not required by law, but are 
expected from companies by the society), and discretionary responsibilities (voluntary activities that make philanthropic contributions) (Carroll 1979, p. 500). However, the Carrol model does not offer a formal theory and does not answer the question of why companies would be motivated to aid society (Clarkson 1995; Jones 1995).

The stakeholder model of CSR later emerged by Freeman in 1984. In this model, companies have the responsibility to create value for the different stakeholders, not only profits for shareholders (Freeman 1984). This model was adopted by many other scholars, such as Jones (1995) and Clarkson (1995). Other scholars modified and broadened the model by adding the financial performance of the company to the model (Rowley 1997; Berman et al. 1999). Famiyeh (2017) utilizes the stakeholder theory to explain the ample evidence of a positive relationship between CSR and a firm's operational capabilities in terms of both cost and flexibility. It reports that CSR and the overall firm's performance, in terms of return on investments, growth in sales, and market share, are evidently related. Based on the stakeholder theory, it is argued that by investing in CSR to meet the expectations of various stakeholders, a firm's reputation and image are enhanced, which eventually affects its financial performance positively.

Other research provided a strategic perspective regarding the responsibility of the firm. For example, Caiado et al. (2018) argue that the firm's responsibility to engage in CSR activities should be included within its strategic plan before it is operationalized by the lower managerial levels. It is observed that having CSR as a strategy enhances the ethical behavioral practices in organizations and recognizes the needs of internal and external stakeholders. However, they document numerous barriers that hinder the integration of CSR into business processes, including cultural, philosophical, social, and economic barriers and even resistance to change. Accordingly, it could be argued that the underlying motives of CSR vary (Galaskiewicz and Colman 2006). The existing literature reveals that CSR antecedents revolve around two major types of possible motives: extrinsic (economic) motives and intrinsic motives (ethical and altruistic).

\subsection{Extrinsic Motives}

Extrinsic motives, or economic motives, are recognized among the main reasons why managers may choose to engage in CSR, according to Graafland et al. (2004). The abundant empirical evidence that is repeatedly documented in the literature, e.g., by Hillman and Keim (2001); Renneboog et al. (2008), and Janamrung and Issarawornrawanich (2015), suggests that there is a direct relationship between CSR and positive corporate financial performance. Such a positive view of CSR implies that CSR and corporate financial success are strongly related. Despite the different possible interpretations for such relation, it could be argued that managerial motivation to engage in CSR is attributable to the perceived positive economic consequences. One view suggests that CSR improves the company's reputation and image, which is considered as a competitive advantage for the company (Miles and Covin 2000). Turban and Greening (1996) provide a broader perspective on the incentive to engage in CSR, as they argue a good corporate reputation not only promotes a firm's products, but it may also attract good potential employees, lead to stronger employee commitment, and reduce employee turnover rates and absenteeism. Similarly, Sen and Bhattacharya (2001) and Gardberg and Fombrun (2006) investigated the relationship between companies' social activities and consumers' purchasing decisions. They report that social activities have a positive reputational impact since social activities can be as important as advertising and R\&D. A very recent study by Ikram et al. (2020) reported that CEOs might be engaging in CSR activities for the sake of increasing their own compensation. Such evidence indicates how managers could perceive CSR engagement, but not the actual impact of such expenditures on corporate financial performance. However, this could not solely be interpreted by agency theory, but also it could be explained by the lack of information that managers need to make ex-post value-maximizing decisions.

Further, Janamrung and Issarawornrawanich (2015) tested the relationships between investment in CSR programs and the firm's financial and market-based performance. Their findings indicate that the more investment in CSR there is, the higher the return on assets (ROA). It has been observed that a positive financial outcome is achieved within two years after the investment. This supports the 
argument that involvement in CSR produces more competitive advantages and reduces litigation costs. However, no relationship is detected between CSR and market-based performance, and this could be due to the short-term period of the study (two years), as the increase in the market value of the firm needs a longer time to be achieved.

Our research investigates whether extrinsic motives are behind a greater engagement in CSR. To avoid confusion, it is worth differentiating between the extrinsic motive (the economic motive) and the financial performance. The extrinsic motive is the managerial perception and belief that CSR is an effective tool to achieve wealth maximization, while financial performance is the actual financial results reported in the firm's financial statements. The effect of the actual financial performance and the extrinsic motives, along with other motives, on CSR is discussed below.

\subsection{Intrinsic Motives}

Hemingway and Maclagan (2004) signify the role that socially responsible managers can play in their societies as "change agents" because they can reflect their personal values regarding CSR in their managerial discretion and implementation of corporate strategies. It is argued that intrinsic motives should be considered in order to understand the overall underlying motives for companies' engagement in CSR. The intrinsic motives for a company evolve when its management perceives CSR as an end in itself, i.e., independent from economic benefits. Graafland et al. (2004) suggest that the existing literature recognizes two types of intrinsic motives that are attributable to engagement in greater CSR: moral obligation (ethical motive) and managers' altruism (altruistic motive).

The moral obligation could be derived from a religious belief. The Bible (Matthew 7:12 n.d.) states, "do to others what you would have them do to you, for this sums up the laws and the prophets". In Islam, Prophet Mohammad said: "Whoever wishes to be delivered from the fire and to enter Paradise should treat the people as he wishes to be treated" (Golden rule in Islam 2017). This motive could also be derived from a moral philosophical theory. Kant's moral theory states that to act morally, one should only be motivated to act in a way that he/she wishes to be treated and should also treat humanity as an end and never as a mere means (Evan and Freeman 1988). According to the moral motive, CSR is not perceived as an enjoyable act, but it is an obligation and the right thing to do (Etzioni 1988).

The altruistic motive indicates that managers may engage in CSR only because of its plausible societal consequences and not because it is a mere obligation (Graafland et al. 2004). Further, this motive is also in accordance with the argument of Schopenhauer (1840, p. 193) that there are incentives for ethical actions, such as compassion, which is defined as "the desire of another's well-being." In our paper, we examine whether intrinsic motives lead to a greater engagement in CSR.

\subsection{The Actual Financial Performance and the Jordanian Context}

Waddock and Graves (1997) argue that higher levels of financial performance may lead to higher levels of CSR. This could be explained by the fact that companies who achieve good financial performance may afford the cost of engaging in CSR. Goergen (2012) claims that managers could possibly afford activities like CSR when there is an abundance of financial resources.

In this research, the hypothesis of a positive effect of financial performance on CSR is tested to explore the consistency of the evidence reported in the literature within the Jordanian context.

Most CSR literature from Jordan focuses on the relation between CSR and the financial aspects of companies. For instance, Abu Abu Farha and Alkhalaileh (2016) examined the relationship between CSR disclosure and both the return on equity (ROE) and stock returns. They documented a positive correlation between CSR disclosure and ROE, but no significant relation with stock returns. Omar and Zallom (2016) investigated the relationship between the market value of the publicly listed firms with different themes of CSR: the environment, human resources, community, and products. Interestingly, he does not find any positive effect of any CSR theme on a firm's market value.

A few studies considered the effect of CSR on other indicators of organizational performance. For example, Abuzanoona (2012) reported a significant positive effect of CSR on the innovation climate 
in the banking sector. Further, Ali et al. (2010), who explored the effect of CSR on different types of organizational commitments, revealed findings of a significant positive effect on affective and normative commitments. In addition, Albdour and Albdour and Altarawneh (2012) empirically tested the effect of CSR on two dimensions of employees' engagement, job engagement and organizational engagement, where a significant positive effect is reported in their findings.

The literature of CSR, especially in the context of developing countries such as Jordan, still needs further research not only to report its effects but also to understand its underlying motives and drivers.

\section{Theoretical Framework}

The objective of this paper is directly linked to the gaps identified in the literature reviewed above. We investigate the effect of two types of motives, extrinsic and intrinsic, as well as the firm's actual financial performance on the level of CSR engagement. We argue that these three main variables play a substantial role in influencing the managerial discretion regarding CSR activities, supported by three recognizable streams of research in the existing literature.

The first stream postulates that extrinsic motives are behind CSR (for example, see Miles and Covin 2000; Turban and Greening 1996; Sen and Bhattacharya 2001; Gardberg and Fombrun 2006). Specifically, it is argued that management perceives CSR as a tool to achieve economic success since it is viewed as

- a competitive advantage among peers;

- a provider of a good corporate reputation;

- a promoter of the firm's products;

- a quality that attracts qualified employees and improves personnel productivity; and

- a value-added activity that is comparable to $R \& D$ and advertising.

The second stream postulates that intrinsic motives are behind CSR (for example, see Hemingway and Maclagan 2004; Graafland and Ven 2006; Graafland et al. 2004). Specifically, it is argued that management perceives CSR as a duty given that managers reflect their personal values towards CSR in their managerial discretion and implementation of corporate strategies driven by:

- $\quad$ an ethical obligation, i.e., managers feel obliged to do it because it is right, not because it is enjoyable; and

- altruism, whereby managers enjoy contributing to the common good and the well-being of others.

The third stream postulates that actual corporate financial performance is behind CSR (for example, see Waddock and Graves 1997; Hillman and Keim 2001; Renneboog et al. 2008; Goergen 2012; Torugsa et al. 2012; Janamrung and Issarawornrawanich 2015). Specifically, it is argued that managers afford activities such as CSR when there is an abundance of financial resources if

- the actual return on assets is better compared to peers; and

- the actual net profit margins are better compared to peers in the same industry sector.

Figure 1 depicts the theoretical framework and illustrates the hypothetical relationships of the study variables. The model proposes that three variables may influence the level of CSR in companies: intrinsic motives (both altruistic and ethical motive), extrinsic motives (the economic motive), and the actual financial performance of the company. The rationale behind this model is that the different motives recognized in literature could stimulate the company to engage more in CSR along with the actual financial performance of that company, where positive financial performance could render engagement in CSR more affordable.

Hence, we posit the following hypotheses:

Hypothesis 1 (H1). CSR is higher if the company's management has greater extrinsic motives to engage in CSR; 
Hypothesis 2 (H2). CSR is higher if the company's management has greater intrinsic motives to engage in CSR;

Hypothesis 2a (H2a). CSR is higher if the company's management has a greater ethical motive;

Hypothesis $\mathbf{2 b} \mathbf{( H 2 b )}$. CSR is higher if the company's management has a greater altruistic motive.

Hypothesis 3 (H3). CSR is higher if the company has a higher actual financial performance.

Hypothesis $\mathrm{H} 1$ examines the influence of the extrinsic motive behind CSR, where CSR would be higher for companies that perceive CSR as an instrument for economic success and are concerned with economic success. Hypothesis $\mathrm{H} 2$ inspects the influence of the intrinsic motives behind CSR, where CSR would be higher for those companies that perceive CSR as a moral obligation, as they are driven by an altruistic behavior to meet their moral obligation. Hypotheses $\mathrm{H} 2 \mathrm{a}$ and $\mathrm{H} 2 \mathrm{~b}$ test whether each of the intrinsic motives (ethical and altruistic motives) separately has an effect on CSR engagement. The emphasis of Hypothesis $\mathrm{H} 3$ is on the actual reported financial performance of the company, where CSR is anticipated to be higher at those companies that enjoy better financial performance.

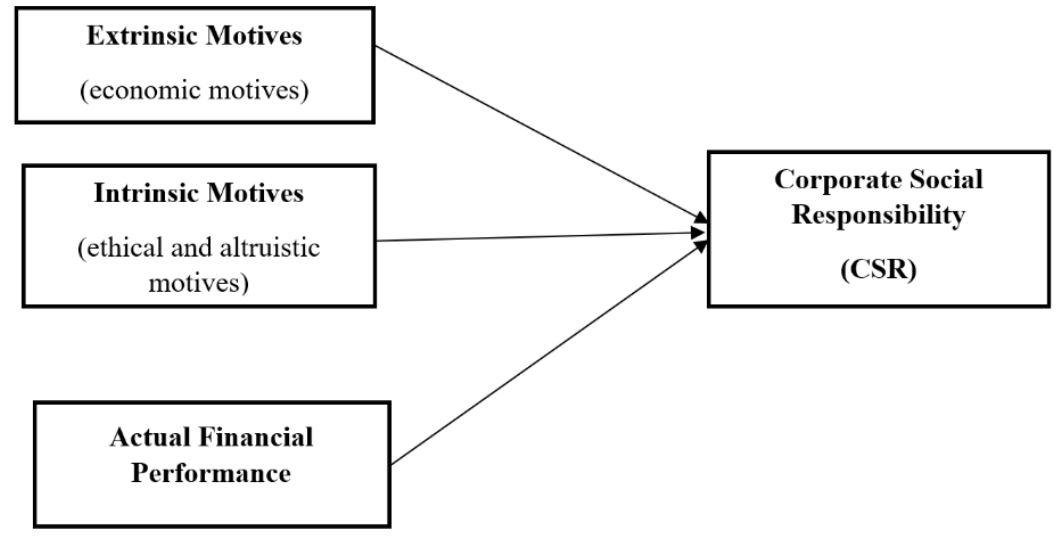

Figure 1. Theoretical framework.

\section{Methodology}

\subsection{Measurements of Variables}

We used a questionnaire reviewed by seven experts (face validity test), six of which are academic researchers in the field of CSR and one of which is a statistician. The experts provided their feedback on the relevance and the clarity of the items included in the questionnaire, which was modified accordingly.

\subsubsection{Measurement of CSR}

We measured the perceptions of managers using a comprehensive scale that measures CSR and depicts its multidimensional structure. Following the existing literature, we measured CSR engagement at firms based on primary data collected from top corporate management, for which a comprehensive scale was developed similar to those used in previous studies, such as those by Turker (2009); Torugsa et al. (2012); Graafland and Ven (2006); and Graafland et al. (2004). Eight categories were formed: employees, society, shareholders, suppliers, competitors, customers, the environment, and the use of instruments. A pool of 32 items was developed based on the abovementioned four previous studies to measure the different aspects of the eight categories. In addition, two more items were addressed: compliance with Jordanian corporate governance code for publicly listed companies, as corporate governance could be part of CSR (Jamali et al. 2008), and the use of external audits, to ensure that the scale is more valid and comprehensive (Graafland et al. 2004). The final scale used to measure CSR consisted of 34 items, presented in Table 1. 
Table 1. This table presents the corporate social responsibility (CSR) measurement tool.

\begin{tabular}{|c|c|c|}
\hline No. & Item & Category \\
\hline 1. & Our company supports employees who want to acquire additional education. & \multirow{9}{*}{ Employees } \\
\hline 2. & Our company offers equal opportunities for minorities. & \\
\hline 3. & Our company offers equal opportunities for women. & \\
\hline 4. & Our company offers equal opportunities to all its employees. & \\
\hline 5. & Our company prevents abuse in the workplace. & \\
\hline 6. & There is an influence of the works council on company policy. & \\
\hline 7. & $\begin{array}{l}\text { The management of our company is primarily concerned with employees' } \\
\text { needs and wants. }\end{array}$ & \\
\hline 8. & Our company contributes to employee safety more than is required by law. & \\
\hline 9. & $\begin{array}{l}\text { Our company policies encourage employees to develop their skills and } \\
\text { careers and offer an individual training program. }\end{array}$ & \\
\hline 10. & Our company has complaint procedures for customers. & \multirow{3}{*}{ Customers } \\
\hline 11. & Our company respects consumer rights beyond the legal requirements. & \\
\hline 12. & Development of a sustainable alternative for customers. & \\
\hline 13. & Our company works on increasing employee attention to the environment. & \multirow{2}{*}{ Environment } \\
\hline 14. & Our company works on reducing pollution more than is required by law. & \\
\hline 15. & Our company prevents inside trading of stocks. & \multirow{2}{*}{ Shareholders } \\
\hline 16. & $\begin{array}{l}\text { Our company adopts a long-term perspective in decision-making in order to } \\
\text { guarantee sufficient cash flow and produce a persistent superior return to } \\
\text { shareholders/owners. }\end{array}$ & \\
\hline 17. & $\begin{array}{l}\text { Our company competes with its rivals in an ethical framework and respect } \\
\text { their intellectual property. }\end{array}$ & Competitors \\
\hline 18. & Our company makes investments to create a better life for future generations. & \multirow{6}{*}{ Society } \\
\hline 19. & $\begin{array}{l}\text { Our company does charity donations, financial support for people, and } \\
\text { activities for the well-being of society. }\end{array}$ & \\
\hline 20. & Our company strives to create employment opportunities. & \\
\hline 21. & Our company tries to help the government/NGO in solving social problems. & \\
\hline 22. & $\begin{array}{l}\text { Our company contributes to the reintegration of the disabled more than is } \\
\text { required by law. }\end{array}$ & \\
\hline 23. & Our company complies with the Jordanian corporate governance code. & \\
\hline 24. & $\begin{array}{l}\text { Our company has control over the labor standards of suppliers for } \\
\text { compliance with legal requirements, i.e., safety, environmental standards. }\end{array}$ & \multirow{3}{*}{ Suppliers } \\
\hline 25. & Our company has a complaints procedure for suppliers. & \\
\hline 26. & Our company performs quality control of supplier products. & \\
\hline 27. & Code of ethics Yes/No & \multirow{8}{*}{$\begin{array}{l}\text { Use of } \\
\text { instruments }\end{array}$} \\
\hline 28. & Ethics committee Yes/No & \\
\hline 29. & Ethical training Yes/No & \\
\hline 30. & Use of external audits Yes/No & \\
\hline 31. & Code of conduct Yes/No & \\
\hline 32. & ISO certification Yes/No & \\
\hline 33. & Social manual Yes/No & \\
\hline 34. & Social reporting Yes/No & \\
\hline
\end{tabular}

Items 1-26 were measured on a scale from 1 to 4 where 1/2/3/4 denote never/rarely/sometimes/always; items 27-34 are yes/no questions; where yes scores 4 and no scores 1 ; for each item, the option of not applicable was added.

\subsubsection{Measurement of the Motives behind CSR}

We followed Graafland et al. (2004) in measuring the extrinsic motive and the intrinsic motives (both ethical and altruistic motive). Each of the extrinsic and the ethical motives depends on two intertwined factors, as shown in the two equations below:

$$
\begin{gathered}
E X M=P I O F P \times R I O F P \\
E t M=P E D \times R I O E D
\end{gathered}
$$


where

- ExM: extrinsic motive;

- $\quad P I O F P$ : the perceived impact of CSR on financial performance;

- RIOFP: the relative importance of financial performance;

- EtM: ethical motive;

- PED: the perception that CSR is an ethical duty;

- RIOED: the relative importance of meeting ethical duty.

The perceived impact of CSR on financial performance is measured by reporting the responses to the following statement: "Our firm's efforts with respect to CSR will have a positive influence on our financial results in the long term." The perception that CSR is an ethical duty is measured by reporting the responses to the following statement: "To behave in a responsible way is a moral duty of businesses toward society." The relative importance of financial performance and the relative importance of meeting the ethical duty are measured by attitudinal questions, based on Carrols' typology (1999), which recognizes four orientations towards CSR: financial, legal, ethical, and philanthropic. The philanthropic orientation is considered as a proxy for the altruistic motive. The intrinsic motives are the sum of the score of both the altruistic motive and the interaction variable of the ethical motive, as illustrated in Table 2.

Table 2. This table presents the measurement of the relative importance of financial performance in panel (1), the relative importance of meeting the ethical duty in panel (2) and the altruistic motive behind CSR in panel (3).

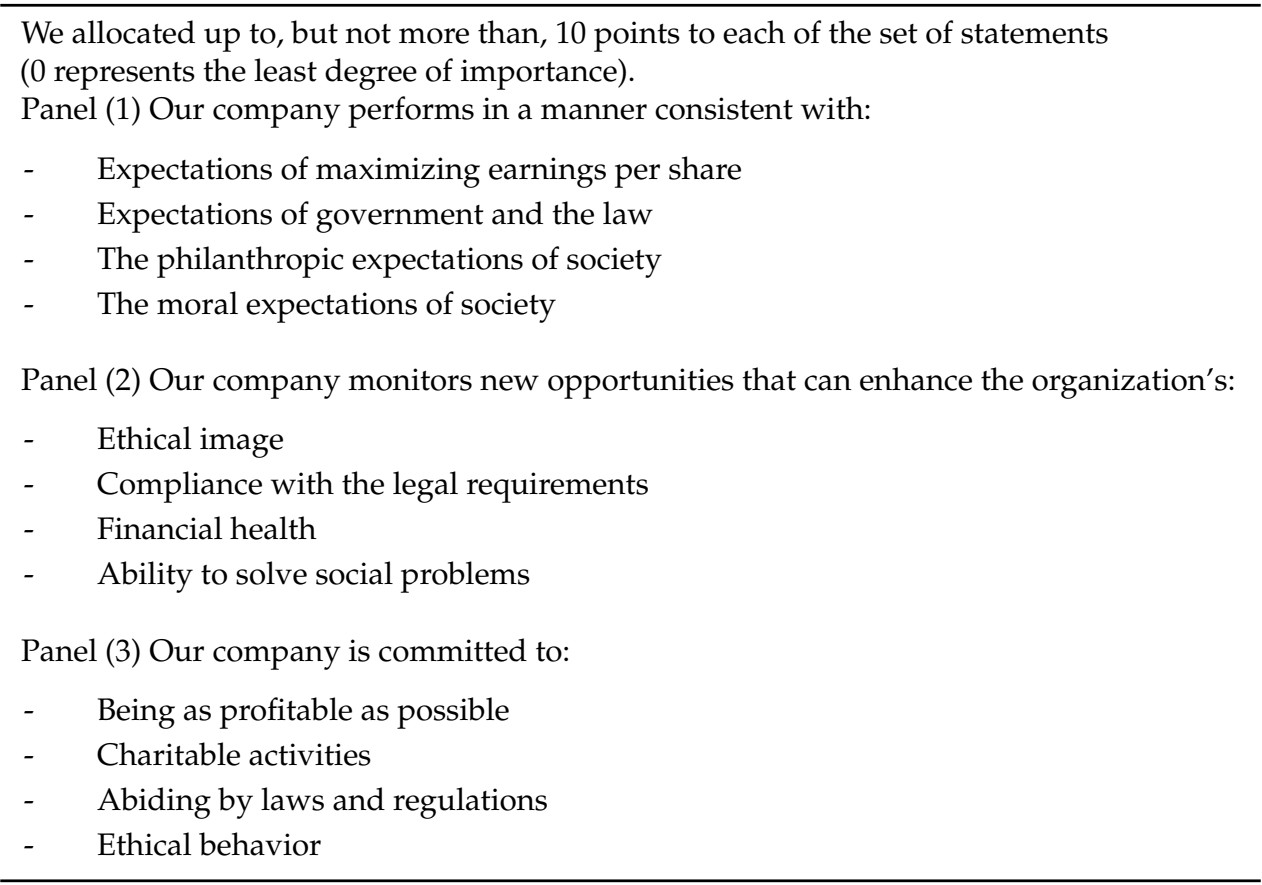

The intertwined factors in both extrinsic and ethical motives were interpreted by capturing their indicative aspects. For the extrinsic motive (the economic motive), CSR was perceived to have a positive impact on the financial performance, whereas this perception did not have much influence if the companies were led by managers who were less concerned about financial performance. In other words, to recognize a high extrinsic motive (the economic motive), CSR must have been perceived as having a high positive impact on the financial performance and as strategically assisting the company in pursuing financial success. For the ethical motive, it was recognized as high if CSR was perceived as an ethical duty, i.e., the company revealed a high commitment to its ethical obligations (Graafland et al. 2004). 
Interestingly, Dare (2016) used the location of the CSR department in the organizational structure as a proxy of the type (intrinsic or extrinsic) of motive. If the CSR department was located under community affairs, corporate governance, or the legal and corporate ethics divisions, then the company had an intrinsic motivation to engage in CSR. On the other hand, if the CSR department was located under public relations, advertising, communication, strategy, marketing, or business development divisions, then the company was expected to have an extrinsic motivation to engage in CSR. This method can eliminate the social desirability response bias, but it was not practical to use in our study because most of the sampled companies did not have a CSR department.

\subsubsection{The Actual Financial Performance}

In our survey, the respondents were asked to rate their companies' financial performance in terms of the return on assets and net profits to sales for the previous year, compared to peers in the same industry sector (Torugsa et al. 2012). This method allowed respondents to share their general perceptions of the company's financial performance, and they were unlikely to provide quantitative data. In fact, the literature shows a high correlation validity between objective and subjective data regarding the performance (Dess and Robinson 1984; Homburg et al. 1999).

\subsubsection{Control Variables}

Several control variables that were likely to influence CSR were included in the regression model. These variables include the type of industry, the size of the company, the age of the company, and whether the company was publicly listed or not. Five industry sectors were recognized (pharmaceutical, financial service, construction, farming, and technology and telecommunication). For the size of the company, four dummy variables were used: very small companies (1-10 employees), small companies (11-50 employees), medium companies (51-250 employees), and large companies (more than 250 employees). For the age of the company, four categories were considered: less than 3 years, more than 3 years, but less than 10 years, more than 10 years, but less than 20 years, and more than 20 years. Finally, a dummy variable was used to indicate whether the company was publicly listed or not.

\subsection{The Population and the Study Sample}

The population of this study was Jordanian companies in five sectors: pharmaceuticals, construction, farming, technology and telecommunication, and financial services. The questionnaire was administered by email and sent to a random sample of the companies. The questionnaire was designed such that the respondent could not move to the next question unless the previous questions were answered. The questionnaire was required to be filled out only by personnel holding a managerial position in the company. The questionnaire was run in a database that includes 1280 companies in the Companies Control Department (CCD) records. A total of 64 complete responses were collected; 37\% of the responses were given by top-level managers, $40.6 \%$ by medium-level managers, and the remaining $22.4 \%$ by low-level managers. The distribution of the sample according to the sector, company age, company size, and listing status of the company is demonstrated in Table 3.

Table 3. This table presents the sample description.

\begin{tabular}{cccccccc}
\hline Sector & $\mathbf{\%}$ & Company Age & $\mathbf{\%}$ & Size & $\mathbf{\%}$ & Public & $\%$ \\
\hline Pharmaceutical & 17.2 & $<3$ years & 15.6 & Very small & 10.9 & Public & 17.2 \\
Financial Services & 18.8 & from 3 to $<10$ years & 37.5 & Small & 43.8 & Non-public & 82.8 \\
Construction & 28.1 & from 10 to $<20$ years & 18.8 & Medium & 18.8 & & \\
Technology \& Telecom & 29.7 & $>20$ years & 28.1 & Large & 26.5 & & \\
Farming & 6.2 & Total & 100 & Total & 100 & Total & 100 \\
Total & 100 & & & & &
\end{tabular}




\section{Empirical Findings and Discussion}

The internal consistency and scale reliability of the measurement tool were examined using the coefficient of Cronbach's alpha. The Cronbach's alpha coefficient was separately obtained for each variable included in the analysis and for each category in the CSR index. According to the results, the internal consistency was satisfactory, as all values were higher than 0.6 , except for the relative importance of meeting the ethical duty and the CSR items concerned with the shareholder category, which had values of 0.564 and 0.532 , respectively. Both were not far below the limit of 0.6 so as to be considered unacceptable (Hair et al. 1998). Therefore, the measurement tool was statistically reliable in achieving its objectives.

\subsection{Descriptive Statistics}

Table 4 presents the descriptive statistics for all variables. On average, the level of engagement with CSR in the sample companies was relatively high, 3.22/4 (80.5\%). In addition, the respondents substantially agreed that CSR could lead to a positive financial performance in the long term and that CSR was an ethical duty of companies.

Table 4. This table presents the descriptive statistics of the study variables.

\begin{tabular}{lccccc}
\hline & Mean & SD & Min & Median & Max \\
\hline CSR & 3.22 & 0.46 & 1.93 & 3.25 & 4.00 \\
\hline Extrinsic Motives & 10.66 & 5.06 & 0 & 11.00 & 21.33 \\
\hline \multicolumn{1}{c}{ Altruistic Motive } & 1.76 & 0.87 & 0.33 & 1.66 & 4 \\
$\quad$ Ethical Motive & 7.50 & 3.00 & 2.66 & 7.5 & 16 \\
Intrinsic Motives & 9.26 & 3.32 & 4 & 9.16 & 17.66 \\
\hline Actual Financial Performance & 3.14 & 0.84 & 1 & 3 & 5 \\
\hline Publicly Listed & 0.17 & 0.38 & 0 & 0 & 1 \\
Pharmaceuticals & 0.17 & 0.38 & 0 & 0 & 1 \\
Construction & 0.28 & 0.45 & 0 & 0 & 1 \\
Farming & 0.06 & 0.24 & 0 & 0 & 1 \\
Tech. \& Comm. & 0.29 & 0.46 & 0 & 0 & 1 \\
Fin. Service & 0.18 & 0.39 & 0 & 0 & 1 \\
Very Small & 0.10 & 0.31 & 0 & 0 & 1 \\
Small & 0.43 & 0.50 & 0 & 0 & 1 \\
Medium & 0.18 & 0.39 & 0 & 0 & 1 \\
Large & 0.26 & 0.44 & 0 & 0 & 1 \\
0-3y & 0.15 & 0.36 & 0 & 0 & 1 \\
3-10y & 0.37 & 0.48 & 0 & 0 & 1 \\
10-20y & 0.18 & 0.39 & 0 & 0 & 1 \\
>20y & 0.28 & 0.45 & 0 & 0 & 1 \\
\hline
\end{tabular}

CSR: is the scaled score of CSR index out of 4 points. Extrinsic Motives: a variable depends on two intertwined factors (the perceived impact of CSR on financial performance $X$ the relative importance of the financial performance), Altruistic Motive: is an ordinal variable indicates the altruistic motive of respondents towards engaging in CSR on a scale 0-10, Ethical Motive: is an ordinal variable measured by interacting two factors (the perception that CSR is an ethical duty $X$ the relative importance of meeting the ethical duty) on a scale $0-40$, Intrinsic Motives: the sum of both ethical motive and the altruistic motive on a scale 0-40, Act. Fin Perform.: ordinal variable that indicates the actual financial performance of the firm on a scale 1-5, Publicly Listed: a binary variable takes 1 if the company is listed and 0 otherwise, Pharma: a binary variable takes 1 if the company is in the pharmaceutical industry and 0 otherwise, Construction: a binary variable takes 1 if the company is in the construction industry and 0 otherwise, Farming: a binary variable takes 1 if the company is in the farming industry and 0 otherwise, Fin. Serv.: a binary variable takes 1 if the company is in the financial services industry and 0 otherwise, Tech \& Comm.: a binary variable takes 1 if the company is in the technology and communication industry and 0 otherwise, Very Small: a binary variable takes 1 if the company has (1-10) employees and 0 otherwise, Small: a binary variable takes 1 if the company has (11-50) employees and 0 otherwise, Medium: a binary variable takes 1 if the company has (51-250) employees and 0 otherwise, Large: a binary variable takes 1 if the company has more than (250) employees and 0 otherwise, $\mathbf{0 - 3 y :}$ a binary variable takes 1 if the company's age is less than 3 years and 0 otherwise, 3-10y: a binary variable takes 1 if the company's age is 3-10 years and 0 otherwise, 10-20y: a binary variable takes 1 if the company's age is 10-20 years and 0 otherwise, $>20 y$ : a binary variable takes 1 if the company's age is greater than 20 years and 0 otherwise. 
The scores on the scale allocating 10 points on four different attitudes revealed that the relative importance of financial success had the highest score (3.32/10), while philanthropic orientation (the altruistic motive behind CSR) had the lowest (1.76/10). Furthermore, the economic motive (extrinsic) on average had a higher score than the intrinsic motives, corresponding to the conclusion that companies are more financially driven to engage with CSR.

\subsection{Empirical Results}

Prior to performing multiple regression analysis, the assumptions of regression were tested: linearity, equal variance, and normality. There was no need to evaluate the assumption of the independence of error, as the data were collected during the same time period (Berenson et al. 2015).

Plots of the residuals against each of the independent variables were produced. There was no clear distinctive pattern among residuals and the independent variables, leading to the conclusion that the linearity assumption was met. Moreover, the plot of residuals against the predicted values of CSR (the dependent variable) to test for homoscedasticity showed that there was no unique pattern. Hence, the assumption of equal variance was met. In addition, the histogram chart of the frequencies of the errors did not significantly depart from the normal distribution, suggesting that the assumption of normality was met.

Further, Table 5 presents the correlation matrix of all independent variables. The correlation matrix indicates that the highest correlation reported was between large companies and companies older than 20 years, with a correlation coefficient of 0.522 , and between publicly listed companies and companies older than 20 years, with a correlation coefficient of 0.452 . Such high correlations signal a likelihood of multicollinearity among independent variables. A variance inflation factor (VIF) test for the independent variables indicated that three of the categorical variables, namely, technology and telecommunication, large companies, and companies older than 20 years, had high multicollinearity. For the other variables, VIF had values below the limit of 5 , indicating no multicollinearity problems (Hair et al. 1998).

The results of the ordinary least square regression analysis (OLS) are presented in Table 6, which reveals that three of the categorical variables (technology and telecommunication, large companies, and companies older than 20 years) could not be estimated and were removed by the used software, due to their high multicollinearity.

The intrinsic motives variable had a positive coefficient that was significant at $p=0.01$, indicating a positive relationship with the level of engagement in CSR and providing evidence to accept Hypothesis H2. The extrinsic motive variable, on the other hand, did not have a significant coefficient, yet it was positive $(p=0.76)$. The latter result was consistent with the perception of managers that CSR should be strategically adopted regardless of its effect on the economic results. A managerial implication could be suggested that, even if financial resources were allocated to strategies or activities to achieve economic success, CSR was still perceived by managers as an important consideration for their firms. The findings reveal further managerial implications where management perceived CSR as a duty because they reflect their personal values regarding CSR in their managerial discretion and implementation of corporate strategies, driven by either their ethical obligation, i.e., they feel obliged to do it, or by their altruistic behavior, i.e., they enjoy contributing to the common good and the well-being of others.

Further, the regression results show that the previous year's actual financial performance had a significant positive coefficient at $p=0.01$, indicating a direct effect on the level of engagement in CSR and providing statistical evidence in support of Hypothesis H3. The aforementioned finding was consistent with the intuition that a company with good financial performance was more able to afford to allocate funds on CSR. An implication could be drawn here that the socially responsible behavior of managers should be constrained by the achievement of other stakeholders' economic objectives. A comparison among the standardized regression coefficients suggests that the actual financial performance variable (0.26) had a greater impact on CSR than the intrinsic motives $(0.17)$. None of the controlling variables had statistically significant coefficients. This means that, in our sample, a firm's engagement in CSR was not related to its listing status, size, age, or sector classification. 
Table 5. This table presents the correlation matrix of all independent variables.

\begin{tabular}{|c|c|c|c|c|c|c|c|c|c|c|c|c|c|c|c|c|c|}
\hline & $\begin{array}{l}\text { Extrinsic } \\
\text { Motives }\end{array}$ & $\begin{array}{l}\text { Intrinsic } \\
\text { Motives }\end{array}$ & $\begin{array}{l}\text { Act. Fin. } \\
\text { Perform. }\end{array}$ & $\begin{array}{c}\text { Publicly } \\
\text { Listed }\end{array}$ & Pharma & Construction & Farming & $\begin{array}{l}\text { Fin. } \\
\text { Serv. }\end{array}$ & $\begin{array}{l}\text { Tech \& } \\
\text { Comm. }\end{array}$ & $\begin{array}{c}\text { Very } \\
\text { Small }\end{array}$ & Small & Medium & Large & $0-3 y$ & $3-10 y$ & $10-20 y$ & $>20 y$ \\
\hline Extrinsic Motives & 1.000 & & & & & & & & & & & & & & & & \\
\hline Intrinsic Motives & -0.472 & 1.000 & & & & & & & & & & & & & & & \\
\hline Act. Fin Perform. & 0.078 & -0.014 & 1.000 & & & & & & & & & & & & & & \\
\hline Publicly Listed & -0.006 & -0.237 & 0.096 & 1.000 & & & & & & & & & & & & & \\
\hline Pharma & 0.166 & -0.057 & 0.047 & 0.012 & 1.000 & & & & & & & & & & & & \\
\hline Construction & -0.143 & 0.199 & -0.249 & -0.193 & -0.285 & 1.000 & & & & & & & & & & & \\
\hline Farming & -0.077 & -0.175 & 0.034 & 0.053 & -0.118 & -0.162 & 1.000 & & & & & & & & & & \\
\hline Fin. Serv. & 0.089 & -0.043 & 0.229 & 0.312 & -0.219 & -0.301 & -0.124 & 1.000 & & & & & & & & & \\
\hline Tech \& Comm. & -0.032 & -0.020 & -0.007 & -0.115 & -0.296 & -0.406 & -0.168 & -0.312 & 1.000 & & & & & & & & \\
\hline Very Small & -0.008 & -0.082 & -0.343 & -0.195 & -0.025 & 0.069 & -0.074 & 0.026 & -0.030 & 1.000 & & & & & & & \\
\hline Small & 0.197 & -0.199 & -0.125 & -0.208 & 0.012 & 0.083 & 0.053 & -0.113 & -0.024 & -0.365 & 1.000 & & & & & & \\
\hline Medium & -0.119 & 0.175 & 0.246 & 0.078 & 0.078 & -0.131 & 0.098 & 0.061 & -0.039 & -0.303 & -0.172 & 1.000 & & & & & \\
\hline Large & -0.221 & 0.155 & 0.290 & 0.406 & -0.072 & 0.040 & 0.000 & 0.092 & -0.059 & -0.462 & -0.263 & -0.218 & 1.000 & & & & \\
\hline $0-3 y$ & 0.022 & -0.118 & -0.181 & -0.147 & 0.138 & 0.037 & 0.138 & -0.017 & -0.209 & 0.292 & -0.147 & 0.041 & -0.186 & 1.000 & & & \\
\hline $3-10 y$ & 0.116 & -0.144 & -0.280 & -0.255 & 0.004 & 0.038 & -0.193 & -0.110 & 0.155 & 0.335 & 0.177 & -0.185 & -0.357 & -0.241 & 1.000 & & \\
\hline $10-20 y$ & -0.104 & 0.207 & 0.239 & -0.024 & -0.024 & -0.143 & 0.030 & 0.056 & 0.097 & -0.086 & -0.024 & 0.161 & -0.022 & -0.162 & -0.378 & 1.000 & \\
\hline$>20 y$ & 0.029 & 0.016 & 0.267 & 0.452 & -0.009 & -0.005 & -0.018 & 0.145 & -0.102 & -0.358 & -0.193 & -0.026 & 0.522 & -0.201 & -0.469 & -0.316 & 1.000 \\
\hline
\end{tabular}

Extrinsic Motives: a variable depends on two intertwined factors (the perceived impact of CSR on financial performance X the relative importance of the financial performance), Intrinsic Motives: the sum of both ethical motive and the altruistic motive on a scale $0-40$, Act. Fin Perform.: ordinal variable that indicates the actual financial performance of the firm on a scale Construction: a binary variable takes 1 if the company is in the construction industry and 0 otherwise, Farming: a binary variable takes 1 if the company is in the farming industry and 0 otherwise, Fin. Serv.: a binary variable takes 1 if the company is in the financial services industry and 0 otherwise, Tech \& Comm.: a binary variable takes 1 if the company is in the technology and communication industry and 0 otherwise, Very Small: a binary variable takes 1 if the company has (1-10) employees and 0 otherwise, Small: a binary variable takes 1 if the company has (11-50) employees and 0 otherwise, Medium: a binary variable takes 1 if the company has (51-250) employees and 0 otherwise, Large: a binary variable takes 1 if the company has more than (250) employees and 0 otherwise, $0-3 y$ : a binary variable takes 1 if the company's age is less than 3 years and 0 otherwise, $3-10 y$ : a binary variable takes 1 if the company has more than (250) employees and 0 otherwise, $0-3 y$ : a binary variable takes 1 if the company's age is less than 3 years and 0 otherwise, 3-10y: a binary variable takes 1 if the
company's age is 3-10 years and 0 otherwise, 10-20y: a binary variable takes 1 if the company's age is $10-20$ years and 0 otherwise, >20y: a binary variable takes 1 if the company's age is greater than 20 years and 0 otherwise. 
Table 6. This table presents the multiple regression results for testing the three main hypotheses by regressing the below independent variales on CSR the dependent variable.

\begin{tabular}{lccc}
\hline & $\begin{array}{c}\text { Unstandardized } \\
\text { Coefficients }\end{array}$ & $\begin{array}{c}\text { Standardized } \\
\text { Coefficients * }\end{array}$ & $p$-Value \\
\hline Extrinsic Motives (H1) & 0.01 & 0.02 & 0.76 \\
Intrinsic Motives (H2) & 0.05 & 0.17 & 0.01 \\
Actual Financial Performance (H3) & 0.30 & 0.26 & 0.00 \\
Publicly Listed & 0.40 & 0.40 & 0.06 \\
Pharma. & 0.22 & 0.22 & 0.21 \\
Construction & 0.03 & 0.03 & 0.81 \\
Farming & 0.22 & 0.22 & 0.38 \\
Fin. Services & 0.06 & 0.06 & 0.72 \\
Very Small & 0.01 & 0.01 & 0.96 \\
Small & 0.15 & 0.15 & 0.42 \\
Medium & -0.12 & -0.12 & 0.50 \\
0-3y & 0.35 & 0.35 & 0.09 \\
3-10y & 0.28 & 0.28 & 0.11 \\
10-20y & 0.06 & 0.06 & 0.70 \\
\hline
\end{tabular}

The $\mathbf{R}$ squared for the model is $32.24 \%$; ${ }^{*}$ Standardized Coefficients are used to directly compare the coefficients and to decide which independent variable has the most impact on the dependent variable, as the magnitude of the coefficient reflects the units of measurement of the independent variable (Montgomery et al. 2007). CSR: is the scaled score of CSR index out of 4 points. Extrinsic Motives: a variable depends on two intertwined factors (the perceived impact of CSR on financial performance $X$ the relative importance of the financial performance), Intrinsic Motives: the sum of both ethical motive and the altruistic motive on a scale 0-40, Act. Fin Perform.: ordinal variable that indicates the actual financial performance of the firm on a scale 1-5, Publicly Listed: a binary variable takes 1 if the company is listed and 0 otherwise, Pharma: a binary variable takes 1 if the company is in the pharmaceutical industry and 0 otherwise, Construction: a binary variable takes 1 if the company is in the construction industry and 0 otherwise, Farming: a binary variable takes 1 if the company is in the farming industry and 0 otherwise, Fin. Services: a binary variable takes 1 if the company is in the financial services industry and 0 otherwise, Very Small: a binary variable takes 1 if the company has (1-10) employees and 0 otherwise, Small: a binary variable takes 1 if the company has (11-50) employees and 0 otherwise, Medium: a binary variable takes 1 if the company has (51-250) employees and 0 otherwise, $\mathbf{0 - 3 y}$ : a binary variable takes 1 if the company's age is less than 3 years and 0 otherwise, 3-10y: a binary variable takes 1 if the company's age is $3-10$ years and 0 otherwise, 10-20y: a binary variable takes 1 if the company's age is 10-20 years and 0 otherwise.

The intrinsic motives in our study were split into ethical and altruistic motives. To examine the effects of these two motives separately on CSR, an ordinary least square analysis was performed whereby these two variables, instead of an overall intrinsic motives variable, were included. The new regression model maintained the linearity assumption since the plots of the residuals against the altruistic motive and ethical motive reveal no clear distinctive pattern among residuals and the independent variables. The regression results are presented in Table 7. Three of the categorical variables (technology and telecommunication, large companies, and companies older than 20 years) could not be estimated due to their high multicollinearity and were therefore excluded. For the other variables, VIF was acceptable and below the limit of five (Hair et al. 1998).

The findings revealed that the ethical motive had a significant positive effect on the level of CSR, providing evidence for Hypothesis $\mathrm{H} 2 \mathrm{a}$, while the variable of altruistic motive was insignificant. A possible explanation for this is that the Jordanian society was described as relatively religious, and religious and ethical obligations, compared to mere altruism, may more strongly motivate CSR. 
Table 7. This table presents the multiple regression results for testing the sub hypotheses by regressing the independent variables below on CSR the dependent variable.

\begin{tabular}{lccc}
\hline & $\begin{array}{c}\text { Unstandardized } \\
\text { Coefficients }\end{array}$ & $\begin{array}{c}\text { Standardized } \\
\text { Coefficients }\end{array}$ & $p$-Value \\
\hline Extrinsic Motives (H1) & 0.02 & 0.11 & 0.23 \\
Ethical Motive (H2a) & 0.04 & 0.13 & 0.03 \\
Altruistic Motive (H2b) & 0.20 & 0.17 & 0.07 \\
Actual Financial Performance (H3) & 0.28 & 0.24 & 0.00 \\
Publicly Listed & 0.40 & 0.40 & 0.06 \\
Pharma & 0.21 & 0.21 & 0.22 \\
Construction & 0.03 & 0.03 & 0.81 \\
Farming & 0.26 & 0.26 & 0.31 \\
Fin. Service & 0.10 & 0.10 & 0.59 \\
Very Small & 0.03 & 0.03 & 0.86 \\
Small & 0.18 & 0.18 & 0.34 \\
Medium & -0.14 & -0.14 & 0.45 \\
0-3y & 0.29 & 0.29 & 0.17 \\
3-10y & 0.21 & 0.21 & 0.24 \\
10-20y & 0.01 & 0.01 & 0.94 \\
\hline
\end{tabular}

The $\mathbf{R}$ squared for the model is $34.88 \%$; CSR: is the scaled score of CSR index out of 4 points. Extrinsic Motives: a variable depends on two intertwined factors (the perceived impact of CSR on financial performance $X$ the relative importance of the financial performance), Altruistic Motive: is an ordinal variable indicates the altruistic motive of respondents towards engaging in CSR on a scale 0-10, Ethical Motive: is an ordinal variable measured by interacting two factors (the perception that CSR is an ethical duty $X$ the relative importance of meeting the ethical duty) on a scale $0-40$, Intrinsic Motives: the sum of both ethical motive and the altruistic motive on a scale 0-40, Act. Fin Perform.: ordinal variable that indicates the actual financial performance of the firm on a scale 1-5, Publicly Listed: a binary variable takes 1 if the company is listed and 0 otherwise, Pharma: a binary variable takes 1 if the company is in the pharmaceutical industry and 0 otherwise, Construction: a binary variable takes 1 if the company is in the construction industry and 0 otherwise, Farming: a binary variable takes 1 if the company is in the farming industry and 0 otherwise, Fin. Serv.: a binary variable takes 1 if the company is in the financial services industry and 0 otherwise, Very Small: a binary variable takes 1 if the company has (1-10) employees and 0 otherwise, Small: a binary variable takes 1 if the company has (11-50) employees and 0 otherwise, Medium: a binary variable takes 1 if the company has (51-250) employees and 0 otherwise, $0-3 y$ : a binary variable takes 1 if the company's age is less than 3 years and 0 otherwise, 3-10y: a binary variable takes 1 if the company's age is 3-10 years and 0 otherwise, 10-20y: a binary variable takes 1 if the company's age is 10-20 years and 0 otherwise.

\section{Conclusions}

The debate on the corporation-society relationship has been ongoing since the evolution of the corporate form of business. The practice and perception of CSR have been investigated in a variety of economies and cultures, and different results are documented. This study investigates the role of the extrinsic and intrinsic motives of managers to engage in CSR activities. The relation between managers' extrinsic motives (wealth maximization) and the firms' engagement in CSR is insignificant, while the firms' engagement in CSR activities is positively associated with the managers' intrinsic motives, both ethical and altruistic.

The positive relation between CSR and intrinsic motives was consistent with the results reported by Graafland and Ven (2006); Galaskiewicz and Colman (2006); and Graafland et al. (2004). This suggests that CSR initiatives are substantially influenced by managers' personal values towards CSR, as the managers' ethical motive may drive them to engage in CSR because it is in line with their religious and cultural beliefs, and their altruistic motive may encourage them to contribute to society.

The Hofstede model of national culture also supports this result. Jordan received a low score on the dimension of individualism in this model. This indicates that people's self-image is defined in terms of "we" instead of "I", and employer and employee relationships are perceived in moral terms (employees is a category of CSR). Moreover, Jordan scores moderately on the dimension of masculinity, which means that society is less driven by competition, achievement, and success, and the dominant value is caring for others. Managers in such a culture strive for consensus and value equality, which is why the impact of extrinsic motivation is not significant in CSR, whereas the ethical motive is. 
Finally, our study reveals that the level of CSR was influenced by the financial performance of a firm's prior year. This is consistent with the position of Waddock and Graves (1997) and Goergen (2012), which is that companies with higher free cash flows spend more on CSR because it is more affordable for them compared to peers with lower free cash flows.

The results imply that policymakers, e.g., should incentivize corporate managers to engage in CSR and should promote CSR as a means of corporate sustainability to achieve economic growth. Furthermore, establishing an index for socially responsible corporations in Jordan could promote engagement in CSR. This study establishes several avenues of further research, such as testing managerial opportunism and relating it to the underlying motives of CSR and investigating the long-term future performance of socially responsible firms in relation to the dominant motives.

Author Contributions: Conceptualization, M.S. and M.A. (Muhannad Atmeh); methodology, M.S. and M.A. (Muhannad Atmeh); validation, M.A. (Malek Alsharairi), M.S. and M.A. (Muhannad Atmeh); formal analysis, M.S.; investigation, M.S.; resources, M.S.; data curation, M.S.; writing-original draft preparation, M.S.; writing一review and editing, M.A. (Muhannad Atmeh) and M.A. (Malek Alsharairi); supervision, M.A. (Muhannad Atmeh); project administration, M.A. (Muhannad Atmeh) and M.A. (Malek Alsharairi). All authors have read and agreed to the published version of the manuscript.

Funding: This research received no external funding.

Conflicts of Interest: The authors declare no conflict of interest.

\section{References}

Abu Farha, Enas, and Mahmoud Alkhalaileh. 2016. The relationship between corporate social responsibility's disclosure and financial performance: An empirical study of Jordanian companies listed on Amman Stock Exchange. Jordan Journal of Business Administration 12: 401-15. [CrossRef]

Abuzanoona, W. T. 2012. The Effect of Corporate Social Responsibility and Organizational Culture on Innovation Climate: Analytical Study on the Banking Sector in Jordan. Available online: https://theses.ju.edu.jo/ Original_Abstract/JUF0725297.pdf (accessed on 15 February 2018).

Albdour, Ali Abbaas, and Ikhlas I. Altarawneh. 2012. Corporate Social Responsibility and Employee Engagement in Jordan. Available online: https://www.researchgate.net/publication/271316888_Corporate_ Social_Responsibility_and_Employee_Engagement_in_Jordan (accessed on 6 July 2018).

Ali, A., Ellisha Nasruddin, and Soh Keng Lin. 2010. The relationship between internal corporate social responsibility and organizational commitment within the banking sector in Jordan. World Academy of Science, Engineering and Technology 67: 262-81.

Barnett, Michael L., and Robert M. Salomon. 2012. Does it Pay to be Really Good? Addressing the Shape of the Relationship Between Social and Financial Performance. Strategic Managment Journal 33: 1304-20. [CrossRef]

Berenson, Mark, David Levine, Kathryn A. Szabat, and Timothy C. 2015. Basic Business Statistics Concepts and Applications. Essex: Pearson.

Berman, Shawn L., Andrew C. Wicks, Suresh Kotha, and Thomas M. Jones. 1999. Does stakeholder orientation matter?: The relationship between stakeholder management models and firm financial performance. Academy of Management Journal 42: 488-506.

Boli, John, and D. Hartsuiker. 2001. World culture and transnational corporations: Sketch of a project. Paper presented at International Conference on Effects of and Responses to Globalization, Istanbul, Turkey, May 21-22.

Bowen, Howard. 1953. Social Responsibilities of the Businessman. New York: Harper \& Row.

Caiado, Rodrigo Goyannes Gusmão, Osvaldo Luiz Gonçalves Quelhas, Janice Helena de Oliveira Dias, Maria de Lurdes Costa Domingos, Sergio Luiz Braga França, and Marcelo Jasmim Meiriño. 2018. Adherence of social responsibility management in Brazilian organizations. Social Responsibility Journal 14: 194-212. [CrossRef]

Carroll, Archie B. 1979. A three-dimensional conceptual model of corporate performance. Academy Management Review 4: 497-505. [CrossRef]

Clarkson, Max. 1995. A Stakeholder Framework for Analyzing and Evaluating Corporate Social Performance. The Academy of Management Review 20: 92-117. [CrossRef] 
Dare, Julia. 2016. Will the Truth Set Us Free? An Exploration of CSR Motive and Commitment. Journal of the Center for Business Ethics 121: 85-122. [CrossRef]

Dess, Gregory G., and Richard B. Robinson Jr. 1984. Measuring organizational performance in the absence of objective measures: The case of the privately-held firm and conglomerate business unit. Strategic Management Journal 5: 265-75. [CrossRef]

Etzioni, Amitai. 1988. The Moral Dimension: Towards a New Economics. New York: The Free Press.

European Commission. 2001. A Sustainable Europe for a Better World: A European Strategy for Sustainable Development. Brussels: European Commission.

Evan, William M., and R. Edward Freeman. 1988. A Stakeholder Theory of the Modern Corporation: Kantian Capitalism. Ethical Theory and Business, 75-84.

Famiyeh, Samuel. 2017. Corporate Social Responsibility and Firm's Performance: Empirical Evidence. Social Responsibility Journal 13: 390-406. [CrossRef]

Freeman, R. 1984. Strategic Management: A Stakeholder Approach. Boston: Pitman.

Freeman, Ina, and Amir Hasnaoui. 2010. The Meaning of Corporate Social Responsibility: The Vision of Four Nations. Journal of Business Ethics 100: 419-43. [CrossRef]

Friedman, Milton. 1970. The Social Responsibility of Business is to Increase its Profits. New York Times Magazine, Sepetmber 13, pp. 122-26.

Galaskiewicz, Joseph, and Michelle Sinclair Colman. 2006. collaboration between corporations and nonprofit organizations. In The Non-Profit Sector: A Research Handbook. Edited by Walter W. Powell and Richard Steinberg. New Haven: Yale University Press, pp. 180-200.

Gardberg, Naomi A., and Charles J. Fombrun. 2006. Corporation Citizenship: Creating Intangible Assets Across institutional Environments. Academy of Management Review 31: 329-46. [CrossRef]

Goergen, Marc. 2012. International Corporate Governance. Harlow: Pearson Education Limited.

Golden rule in Islam. 2017. Qur'an Today. Available online: http:/quraan-today.blogspot.com/2014/01/goldenrule-in-Islam-treat-others-as.html (accessed on 21 May 2018).

Graafland, Johan, and Bert Van de Ven. 2006. Strategic and Moral Motivation for Corporate Social Responsibility. Journal of Corporate Citizenship 22: 111-23. [CrossRef]

Graafland, Johan, and Corrie Mazereeuw-Van der Duijn Schouten. 2012. Motives for Corporate Social Responsibility. De Economist 160: 377-96. [CrossRef]

Graafland, Johan J., Sylvester C. W. Eijffinger, and H. SmidJohan. 2004. Benchmarking of Corporate Social Responsibility: Methodological Problems and Robustness. Journal of Business Ethics 53: 137-52. [CrossRef]

Hair, Joseph F., Ralph E. Anderson, Ronald L. Tatham, and William C. Black. 1998. Multivariate Data Analysis. New Jersey: Prentice Hall.

Hemingway, Christine A., and Patrick W. Maclagan. 2004. Managers' personal values as drivers of corporate social responsibility. Journal of Business Ethics 50: 33-44. [CrossRef]

Hillman, Amy J., and Gerald D. Keim. 2001. Shareholder value, stakeholder management, and social issues: What's the bottom line? Strategic Managment Journal 22: 125-39. [CrossRef]

Hofstede Insights. 2020. Available online: https:/www.hofstede-Insights.com/country-comparison/jordan/ (accessed on 12 May 2020).

Homburg, Christian, Harley Krohmer, and John P. Workman. 1999. Strategic consensus and performance: The role of strategy type and market-related dynamism. Strategic Management Journal 20: 339-57. [CrossRef]

Ikram, Atif, Zhichuan Frank Li, and Travis MacDonald. 2020. CEO Pay Sensitivity (Delta and Vega) and Corporate Social Responsibility. Sustainability 12: 7941. [CrossRef]

Jamali, Dima, Asem M. Safieddine, and Myriam Rabbath. 2008. Corporate Governance and Corporate Social Responsibility Synergies and Interrelationships. Corporate Governance: An International Review 16: 443-59. [CrossRef]

Janamrung, Benjamas, and Panya Issarawornrawanich. 2015. The association between corporate social responsibility index and performance of firms in industrial products and resources industries: Empirical evidence from Thailand. Social Responsibility Journal 11: 893-903. [CrossRef]

Jones, Thomas M. 1995. Instrumental stakeholder theory: A synthesis of ethics and economics. Academy of Management Review 20: 404-37. [CrossRef]

Lee, Min-Dong Paul. 2008. A review of the theories of corporate social responsibility: Its evolutionary path and the road ahead. International Journal of Management Reviews 10: 53-73. [CrossRef] 
Matten, Dirk, and Jeremy Moon. 2008. "Implicit" and "explicit" CSR: A conceptual framework for a comparative understanding of corporate social responsibility. The Academy of Management Review 33: 404-24. [CrossRef]

Matthew 7:12. n.d. Bible Gateway. Available online: https:/www.biblegateway.com/passage/?search=Matthew +7 : 12 (accessed on 3 February 2017).

McWilliams, Abagail, and Donald Siegel. 2001. Corporate social responsibility: A theory of the firm perspective. Academy ofManagement Review 26: 117-27.

Miles, Morgan P., and Jeffrey G. Covin. 2000. Environmental marketing: A source of reputational, competitive. Journal of Business Ethics 23: 299-311. [CrossRef]

Montgomery, Douglas C., Elizabeth A. Peck, and G. Geoffrey Vining. 2007. Introduction to Linear Regression Analysis, 4th ed. Hoboken: John Wiley \& Sons Inc.

Omar, Bilal Fayiz, and Nidal Omar Zallom. 2016. Corporate social responsibility and market value: Evidence from Jordan. Journal of Financial Reporting and Accounting 14: 2-29. [CrossRef]

Renneboog, Luc, Jenke Ter Horst, and Chendi Zhang. 2008. The price of ethics: Evidence from socially responsible mutual funds around the world. Journal of Corporate Finance 14: 302-22. [CrossRef]

Rowley, Timothy J. 1997. Moving Beyond Dyadic Ties: A Network Theory of Stakeholder Influences. Academy of Management Review 22: 887-910. [CrossRef]

Schopenhauer, Arthur. 1840. On the Basis of Morality. Translated by E. F. Payne. Ann Arbor: The University of Michigan, New York: Berghahn Books.

Sen, Sankar, and Chitra Bhanu Bhattacharya. 2001. Does Doing Good Always Lead to Doing Better? Consumer Reactions to Corporate Social Responsibility. Journal of Marketing Research 38: 43-62. [CrossRef]

Stovall, O. Scott, John D. Neill, and David Perkins. 2004. Corporate Governance, Internal Decision Making, and the Invisible Hand. Journal of Business Ethics 51: 221-27. [CrossRef]

Torugsa, Nuttaneeya Ann, Wayne O'Donohue, and Rob Hecker. 2012. Capabilities, Proactive CSR and Financial Performance in SMEs: Empirical Evidence from an Australian Manufacturing Industry sector. Journal of Business Ethics 109: 483-500. [CrossRef]

Turban, Daniel B., and Daniel W. Greening. 1996. Corporate social performance and organizational attractiveness. Academy of Management Journal 40: 658-72.

Turker, Duygu. 2009. Measuring Corporate Social Responsibility: A Scale Development Study. Journal of Business Ethics 85: 411-27. [CrossRef]

Waddock, Sandra A., and Samuel B. Graves. 1997. The Corporate Social Performance-Financial Performance Link. Strategic Managment Journal 18: 303-19. [CrossRef]

Wallich, H. C., and J. J. Mcgowan. 1970. A New Rationale for Corporate Social Policy. New York: Committee for Economic Development.

Publisher's Note: MDPI stays neutral with regard to jurisdictional claims in published maps and institutional affiliations.

(C) 2020 by the authors. Licensee MDPI, Basel, Switzerland. This article is an open access article distributed under the terms and conditions of the Creative Commons Attribution (CC BY) license (http://creativecommons.org/licenses/by/4.0/). 